\title{
Pelatihan Implementasi Pendekatan Onto-Semiotik dalam Pembelajaran di Kelas bagi Guru SMP Al-Bahjah Tulungagung
}

\author{
Dian Septi Nur Afifah ${ }^{1}$ \\ ${ }^{1}$ STKIP PGRI Tulungagung
}

\begin{tabular}{|c|c|}
\hline Article History & ABSTRACT \\
\hline $\begin{array}{l}\text { Received 06.04.2019 } \\
\text { Received in revised form } \\
28.07 .2019 \\
\text { Accepted } 29.09 .2019 \\
\text { Available online } 28.10 .2019\end{array}$ & $\begin{array}{l}\text { TRAINING ON THE IMPLEMENTATION OF ONTO-SEMIOTIC APPROACH } \\
\text { IN CLASS LEARNING FOR TEACHERS AT JUNIOR HIGH SCHOOL AL- } \\
\text { BAHJAH TULUNGAGUNG. The purpose of this community service activity is } \\
\text { the teachers training by implementing an onto-semiotic approach in classroom } \\
\text { learning and produce a lesson plan. This activity done at Junior High School Al- } \\
\text { Bahjah Tulungagung. The participants are teachers in Junior High School Al- } \\
\text { Bahjah Tulungagung. The method used is theory method and practice. The results } \\
\text { obtained throught this training are knowldge of innovative learning with an onto- } \\
\text { semiotic approach for teachers and their ability to create and implement the lesson } \\
\text { plan with an onto-semiotic approach. }\end{array}$ \\
\hline & KEYWORDS: Onto-Semiotic Approach, Training. \\
\hline
\end{tabular}

DOI: $10.30653 / 002.201943 .135$

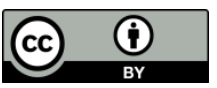

This is an open access article distributed under the terms of the Creative Commons Attribution 4.0 International License, which permits unrestricted use, distribution, and reproduction in any medium, provided the original work is properly cited. ๑ 2019 Dian Septi Nur Afifah.

\section{PENDAHULUAN}

SMP Al-Bahjah Tulungagung merupakan sekolah islam Qurani yang memiliki visi menjadikan peserta didik/santri SMP Al-Bahjah sebagai pengemban Al-Qur'an, berakhlakul karimah, cerdas dalam IPTEK dan mahir dalam berbahasa. Letak SMP AlBahjah di Jalan Raya Karangrejo Sendang Tulungagung. Dalam pembelajaran santri putra dan putri terpisah. Semua santri bermukim di pondok Al-Bahjah Tulungagung.

SMP Al-Bahjah ini baru berdiri dua tahun sehingga masih terdapat dua tingkatan kelas yaitu kelas VII dan VIII, sehingga sarana dan prasana yang mendukung kegiatan pembelajaran dapat dikatakan masih kurang. Berdasarkan hasil observasi peneliti saat pembelajaran di kelas kondisi kelas juga susah dikondisikan. Dan berdasarkan wawancara dengan beberapa santri peneliti dapat menyimpulkan pembelajaran masih didominasi oleh guru sehingga siswa kurang aktif di kelas. Selain itu guru juga monoton

${ }^{1}$ Corresponding author: Program Studi Pendidikan Matematika, STKIP PGRI Tulungagung; Jl. Mayor Sujadi Timur No. 7, Tulungagung; Email: dian.septi@stkippgritulungagung.ac.id 
menggunakan pembelajaran ceramah sehingga guru tidak dapat mengetahui apakah siswa sudah memahami materi yang disampaikan.

Pendekatan onto-semiotik merupakan salah satu pendekatan yang memperhatikan makna dari setiap objek matematika (Font, Godino, \& Amore, 2015). Objek matematika dalam pendekatan onto-semiotik menurut Godino, Batanero, \& Roa, (2005); (Godino, Font, Wilhelmi, \& Lurduy, (2011b); Montiel, Wilhelmi, Vidakovic, \& Elstak, (2009); meliputi bahasa, situasi masalah, konsep, prosedur, proposisi dan argumen. Sedangkan menurut Neto, Breda, Costa, \& Godino, (2007) objek matematika dalam pendekatan ontosemiotik meliputi bahasa, konsep/ properties, prosedur dan argumen. Begitu juga dengan Godino, Batanero, \& Font, (2007) menyatakan bahwa objek matematika dalam pendekatan onto-semiotik adalah masalah, bahasa, tindakan, definisi dan sifat-sifat, dan argumen.

Godino dan Pino-fan (2013) menyatakan bahwa pendekatan onto-semiotik sebagai alat yang menjelaskan didaktik yang ditujukan terhadap efektifitas di dalam kelas. Pendekatan onto-semiotik, dapat memberikan konstribusi dalam desain instruksional matematika (Font, Godino, \& Gallardo, 2012). Sehingga dengan menggunakan pendekatan onto-semiotik dapat memaksimalkan pemahaman siswa terhadap materi yang dipelajari (Afifah, 2016). Untuk itu diperlukan pelatihan guru-guru SMP AL-Bahjah dalam menggunakan menggunakan pendekatan onto-semiotik dalam membuat RPP. Dengan adanya RPP dengan pendekatan onto-semuotil ini diharapkan guru lebih terarah dan fokus sesuai dengan tujuan pembelajaran yang direncanakan. Dan komponen RPP sesuai dengan Permendikbud no.22 tahun 2016.

Adapun tujuan dari pelatihan ini adalah untuk menambah pengetahuan konsep pendekatan onto-semiotik dalam pembelajaran guru-guru SMP Al-Bahjah dan untuk menghasilkan RPP.

\section{METODE PELAKSANAAN}

Pelatihan merupakan salah satu cara pengembangan dan peningkatan kompetensi guru. Hal ini seiring dengan adanya pergantian kebijakan mengenai jabatan fungsional guru dan angka kreditnya yang tertuang dalam Peraturan menteri pendayagunaan aparatur Negara dan Reformasi Birokrasi No. 16 tahun 2009, guru wajib melakukan kegiatan pengembangan keprofesian berkelanjutan diantaranya melalui pendidikan dan pelatihan. Pendidikan dan pelatihan bagi guru perlu dioptimalkan. Untuk itu peneliti melalui kegiatan pelatihan guru-guru SMP Al-Bahjah berupaya mengubah paradigma guru serta memberikan tambahan pengetahuan dan keterampilan yang dapat diimplementasikan dalam pembelajaran di kelas, khususnya dalam pengelolaan pembelajaran sehingga tujuan pembelajaran tercapai.

Metode yang dilakukan dalam kegiatan pengabdian kepada masyrakat ini melalui pelatihan ini ada dua tahap kegiatan. Kegiatan yang pertama yaitu teoritik. Kegiatan yang bersifat teoritik ini dilakukan dengan menyampaikan materi tentang pendekatan ontosemiotik serta penggunaannya dalam mengatasi permasalah di kelas. Pada tahap ini diawali dengan memberikan motivasi kepada guru terkait pentingnya penggunaan inovasi dalam pembelajaran di kelas sehingga kegiatan belajar mengajar di kelas tidak monoton. Selain itu menjelaskan karakteristik tentang pendekatan onto-semiotik. 
Selanjutnya dengan menjelaskan cara menggunakan pendekatan onto-semiotik ini pada RPP baik itu pada kurikulum KTSP maupun kurikulum 2013. Selama pemberian materi ini, guru juga diberikan kesempatan untuk berdiskusi menyampaikan pendapat maupun pertanyaan terkait materi yang belum dipahami.

Tahap kedua yaitu metode praktis yang mana guru diajak untuk menyusun RPP menggunakan pendekatan onto-semiotik yang telah disampaikan sebelumnya. Kegiatan ini bertujuan untuk melatih keterampilan guru dalam menggunakan pendekatan ontosemiotik pada rancangan pembelajaran yang akan digunakan pada pembelajaran di kelas.. Sebelumnya guru telah diinformasikan untuk membawa perlengkapan penyusunan RPP seperti laptop serta RPP yang telah disusun sebelumnya, sehingga konsentrasi guru dapat terfokus pada pengimplementasian pendekatan pembelajaran.

PERMASALAHAN MITRA

1. Pasifnya siswa di kelas

2. Penggunaan metode ceramah

3. Pemahaman siswa terhadap materi kurang

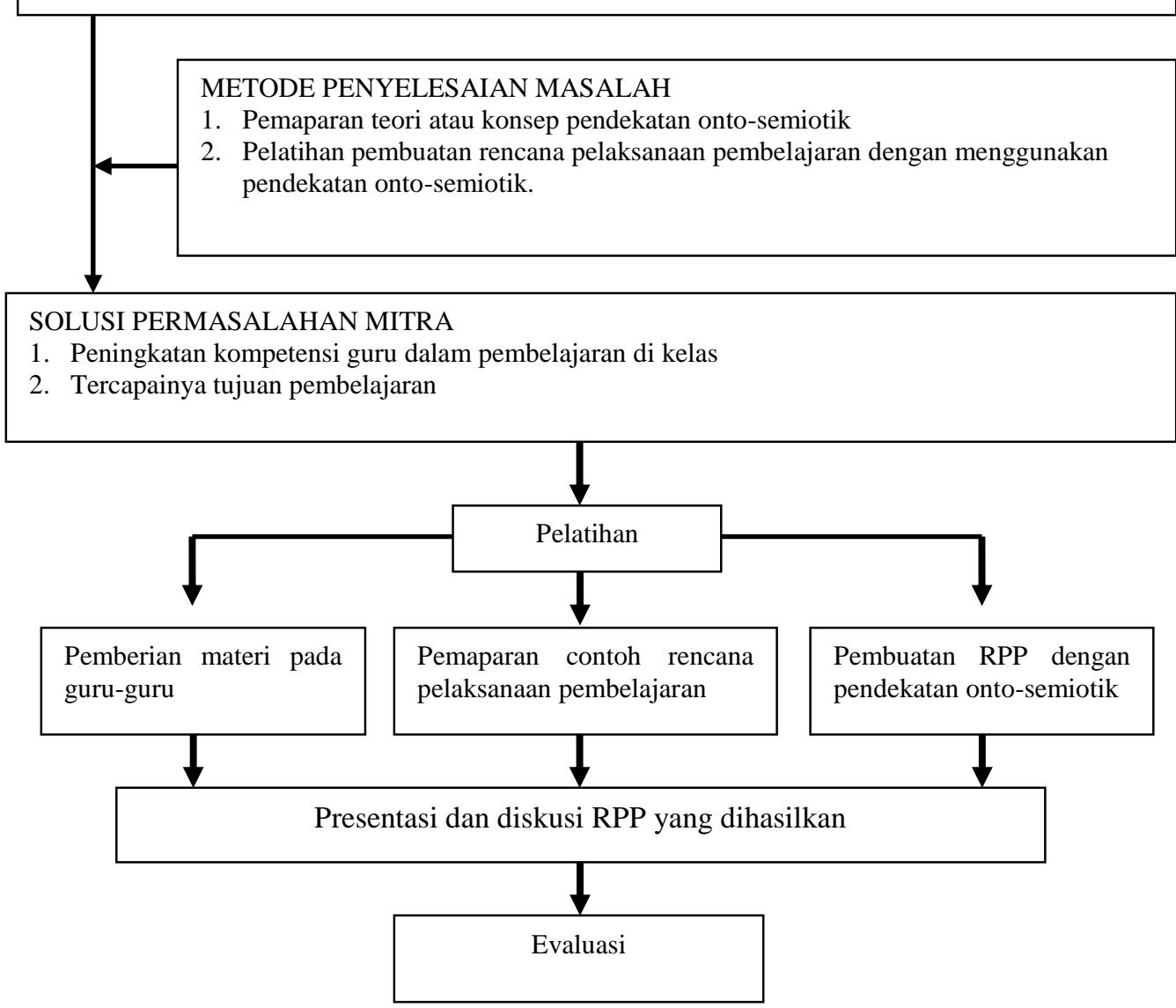

Gambar 1. Alur Kegiatan Pelatihan

Setelah melakukan latihan dalam menyusun RPP menggunakan model pembelajaran tersebut kemudian guru mempresentasikan hasil RPP yang telah dibuat dan ditanggapi dan didiskusikan bersama perserta lainnya serta narasumber sehingga memperoleh pemahaman yang sama antara satu peserta dan peserta lainnya. Berdasarkan RPP yang telah dibuat tersebut, kemudian guru mensimulasikan model pembelajaran 
pada kegiatan belajar mengajar. Hal ini dilakukan untuk memberikan pengalaman langsung dan melatih keterampilan guru secara langsung dalam menggunakan pendekatan onto-semiotik pada proses pembelajaran di kelas. Kegiatan ini dilakukan melalui proses pendampingan peneliti pada peserta kegiatan. Setelah itu dilakukan diseminasi kepada guru-guru lainnya. Berikut adalah desain metode kegiatan pelatihan ini dapat digambarkan dalam bentuk flow chat pada Gambar 1.

\section{HASIL DAN PEMBAHASAN}

Kegiatan pengabdian pada masyarakat ini akan dilaksanakan di SMP Al-Bahjah Tulungagung Jawa Timur. Letak SMP ini di jalan raya karangerejo Tulungagung. Jarak dari Kota Tulungagung ke SMP ini sekitar 10 KM. SMP Al-Bahjah merupakan sekolah yang berbasis pondok pesantren. Semua siswa nya wajib bermukim di pondok. Semua aktivitas siswa laki-laki dan siswa perempuan terpisah. Siswa mayoritas berasal dari luar Tulungagung, seperti Jakarta, Cirebon, Bandung, dan Blitar. Jumlah siswa laki-laki kelas VII adalah 18 dan jumlah siswa perempuan 8. Sedangkan untuk kelas VIII jumlah siswa sebanyak 23 laki-laki dan 7 perempuan. Sekolah ini baru berdiri tahun 2016. SMP ALBahjah lokasinya jadi satu dengan SD, PAUD dan TK di pondok pesantren Al- Bahjah Tulungagung. Jumlah guru ada 12 orang. Jumlah ruang kelas ada lima. Gambar 2 menyajikan situasi tentang SMP Al-Bahjah Tulungagung.

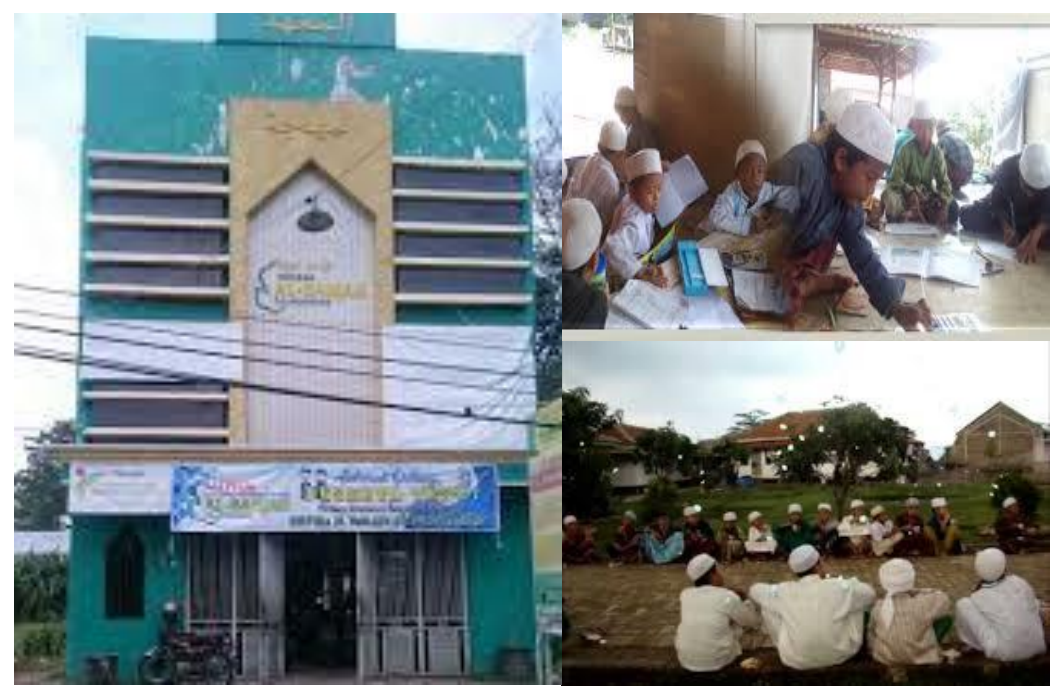

Gambar 2. Situasi SMP Al-Bahjah Tulungagung

Kegiatan pelatihan ini diikuti oleh 15 guru-guru SMP AL-Bahjah Tulungagung. Kegiatan ini dilaksanakan di Aula SMP AL-Bahjah Tulungagung pada tanggal 27 Desember 2018 mulai pukul 09.00 sd pukul 15.00 WIB. Secara umum kegiatan pelatihan ini berjalan dengan lancar. Setelah kegiatan pelatihan ini diharapkan guru-guru SMP ALBahjah Tulungagung dapat mengetahui konsep pendekatan onto-semiotik dan dapat mengimplementasikan dalam Rencana Perangkat Pembelajaran (RPP) sesuai mata pelajaran yang di ampu. Gambaran hasil pelatihan pada setiap tahapan dapat disampaikan sebagai berikut. 


\section{Koordinasi dengan pihak sekolah}

Koordinasi dilakukan untuk meminta ijin kepada pihak sekolah yaitu kepala sekolah SMP AL-Bahjah Tulungagung dengan memberikan proposal pelatihan ini. Setelah satu minggu kemudian pihak sekolah menginformasikan bahwa pelatihan dapat dilakukan ketika libur semester gasal yang bertempat di aula agar tidak menganggu pembelajaran di SMP AL-Bahjah Tulungagung. menentukan waktu dan tempat kegiatan pelatihan.

\section{Penyampaian konsep pendekatan onto-semiotik}

Peserta dari pelatihan ini adalah semua guru-guru SMP Al-Bahjah Tulungagung. Narasumber menyampaikan materi atau konsep pendekatan onto-semiotik menggunakan LCD. Adapun konsep yang disampaikan adalah karakteristik dari pendekatan onto semiotik, dan implementasi dalam rencana perangkat pembelajaran. Dalam penyampaian materi ini terjadi respon yang positif dari peserta pelatihan ini. hal ini dapat ditunjukkan dengan beberapa peserta yang bertanya dan memberi tanggapan.

Sebelum materi disajikan, narasumber bertanya kepada peserta, apa saja yang menjadi kendala kegiatan pembelajaran di kelas. Dari beberapa jawaban peserta dapat disimpulkan bahwa siswa ketika dikelas nampaknya memahami materi yang disampaikan, akan tetapi jika diberi soal atau pertanyaan pada diam tidak bisa menjawab. Hal tersebut menunjukkan siswa tidak paham akan materi yang sudah disampaikan oleh guru, akibatnya hasil belajar rendah dan tujuan pembelajaran tidak tercapai. Selain itu, narasumber juga bertanya, model pembelajaran apa saja yang digunakan selama ini di kelas. Mayoritas peserta menggunakan model pembelajaran langsung. Karena menurut peserta model tersebut yang mudah diterapkan di kelas.

Dalam pendekatan onto-semiotik ini juga dapat digunakan dalam model pembelajaran langsung. Narasumber memaparkan karakteristik dan kelebihan dari dari pendekatan ini. Unsur-unsur penting yang terdapat dalam pendekatan onto-semiotik adalah bahasa, konsep, prosedur, kompuitasi (jika ada), proposisi dan argument (Font et al., 2015). Dalam pendekatan onto-semiotik, siswa mulai memahami dari bahasa (istilahistilah, simbol-simbol, tanda-tanda, gambar, grafik, yang digunakan). Dari bahasa yang digunakan siswa dapat memahami konsep yang ada dalam bahasa tersebut dan menggabungkan antara konsep yang satu dengan konsep yang lain. Untuk mengetahui apakah siswa sudah memahami konsep tersebut atau belum, guru dapat meminta siswa untuk memberikan yang merupakan contoh dari konsep maupun non contoh.

Setelah memahami konsep, selanjutnya memahami prosedur. Siswa memahami prosedur menyelesaikan masalah atau soal dengan menggunakan konsep yang sudah dipahami sebelumnya. Khusus untuk ilmu eksak (matematika, IPA) dapat memahami komputasi dengan benar, termasuk penggunakan rumus dan perhitungan yang benar. Kemudian siswa dapat memahami proposisi dengan memberikan kesimpulan. Dan yang terakhir adalah argument. Dalam memahami apa yang sudah dipelajari, siswa diminta untuk memberikan alasan dari setiap jawabannya, sehingga siswa benar-benar memahami apa yang dikerjakan.

Kelebihan dari penggunaan pendekatan onto-semiotik ini, siswa tidak hanya memahami dari konsep saja, tetapi siswa dapat memahami mulai dari bahasa yang digunakan, konsep, prosedur, komputasi, proposisi dan argument dari setiap materi pelajaran yang di pelajari di kelas. Selain itu penilaian juga dapat dilakukan berdasarkan 
unsur-unsur dalam pendekatan onto-semiotik, sehingga penilaian lebih ke proses dari pada produk (Godino, Font, Wilhelmi, \& Lurduy, 2011a).

Hal ini juga sesuai dengan tujuan pembelajaran matematika. Untuk itu dapat disarankan bahwa pendekatan ini dapat digunakan untuk semua model pembelajaran sesuai kurikulum yang berlaku.

Setelah menyampaikan konsep tentang pendekatan onto-semiotik, narasumber menampilkan salah satu contoh RPP dengan menggunakan model pembelajaran langsung dengan pendekatan onto-semiotik melalui slide powerpoint. Contoh RPP yang ditampilkan adalah pada mata pelajaran matematika, sehingga Nampak unsur komputasi pada pendekatan onto-semiotik karena termasuk ilmu eksak.

Selanjutnya narasumber minta kepada peserta untuk membuat RPP dengan menggunakan model pembelajaran bebas (sesuai dengan keinginan peserta) dengan menggunakan pendekatan onto-semiotik sesuai mata pelajaran yang diampu dalam satu kali pertemuan. Kemudian dilakukan diskusi tentang RPP yang sudah dibuat. Diskusi berjalan dengan lancar, karena hampir semua peserta bertanya dan saling menanggapi peserta satu dengan peserta yang lain. RPP yang dihasilkan ada yang ditulis tangan dan ada tangan, karena tidak semua peserta membawa laptop. Narasumber minta kepada peserta untuk mengimplementasikan RPP yang telah dibuat di semester genap ini.

\section{Implementasi pendekatan onto-semiotik dalam RPP}

Implementasi RPP yang telah dibuat diimplementasikan oleh guru kepada kelasnya masing-masing pada awal semester genap yaitu pada bulan januari. Minggu ketiga bulan januari, pelaksana pengabdian ini datang ke sekolah lagi untuk melihat hasil implementasi RPP yang telah dibuat tersebut. Namun pihak sekolah tidak memberikan waktu untuk mengumpulkan lagi semua guru-guru untuk mempresentasikan hasil implementasi RPP karena guru-guru menyiapakan UNBK 2019. Sehingga kepala sekolah memberikan ijin untuk melakukan wawancara ke beberapa guru yang tidak terlibat UNBK.

Berdasarkan hasil wawancara dengan beberapa guru, dapat disimpulkan beberapa hal yaitu pendekatan onto-semiotik mudah diterapkan baik menggunakan model pembelajaran langsung maupun kooperatif, siswa antusias merespon pembelajaran di kelas, siswa lebih aktif, pemahaman siswa terhadap materi meningkat.

\section{Faktor Pendukung Pelatihan}

Beberapa faktor pendukung terlaksana nya pelatihan ini adalah Kepala sekolah di sekolah mitra yaitu SMP AL-Bahjah Tulungagung sangat mendukung pelatihan ini berlangsung dengan menyediakan tempat pelaksanaan dan peserta pelatihan. Selain itu antusiasme peserta pelatihan yaitu guru-guru SMP Al Bahjah Tulungagung untuk mengikuti pelatihan ini dan menerapkan RPP dengan pendekatan onto-semiotik di dalam kelas.

\section{Kendala dalam Pelatihan}

Kendala dalam pelatihan ini meliputi keterbatasan waktu yang diberikan oleh pihak sekolah, sehingga tidak terlaksana nya presentasi hasil implementasi RPP di kelas karena aktivitas kegiatan di sekolah dan kurangnya tersedia nya media dalam hal ini LCD di dalam setiap kelas, sehingga tidak semua guru menggunakan media power point. 


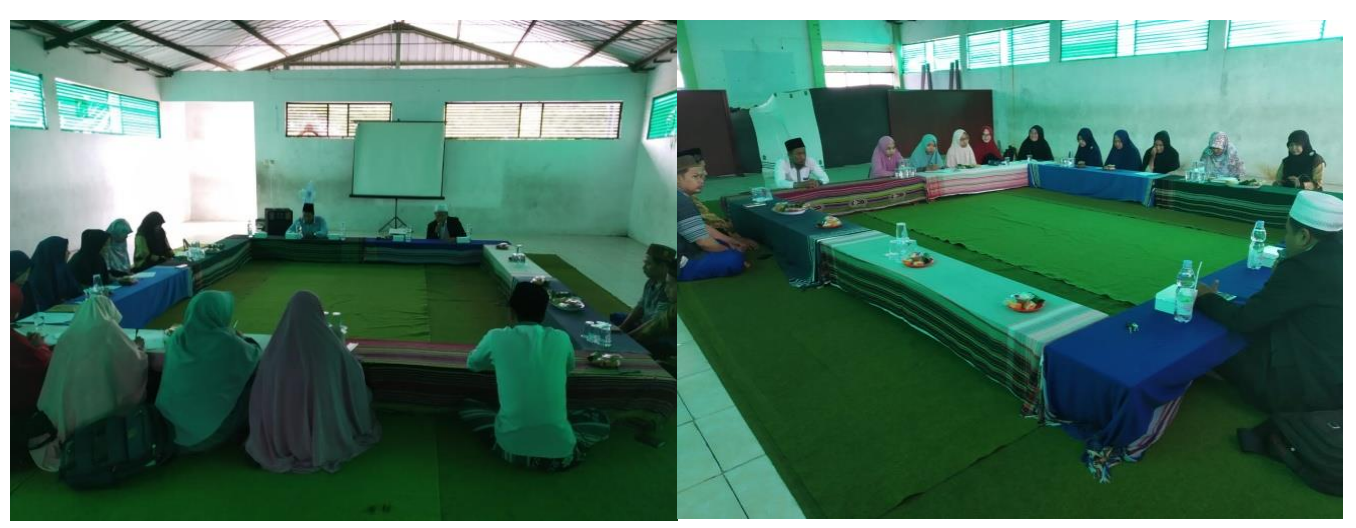

Gambar 3. Dokumentasi Selama Kegiatan Pelatihan

\section{SIMPULAN}

Adapun kesimpulan pada pelatihan kegiatan pengabdian kepada masyarakat ini adalah sebagai berikut: 1) Konsep dari pendekatan onto semiotik terdapat enam unsure penting yaitu bahasa, konsep, prosedur, komputasi (ilmu eksak), proposisi, dan argumen. 2) Pembuatan dan implementasi RPP berjalan dengan lancar dan responsif.

Berdasarkan hasil pelatihan implementasi pendekatan onto-semiotik guru-guru SMP AL-Bahjah Tulungagung dalam pembelajaran di kelas dapat disarankan bahwa pendekatan onto-semiotik dapat diterapkan untuk semua model pembelajaran. Dampak dari hasil implementasi pendekatan onto-semiotik adalah dapat meningkatkan pemahaman siswa terhadap materi yang dipelajari dan menjadikan siswa aktif.

\section{REFERENSI}

Afifah, D. S. N. (2016). Onto semiotic approach profile of senior high school student basen on cognitive style in solving statistics problem. ICMSE : Contribution of Mathematics and Science Research for Sustainable Life in Facing Global Challenge, 3(1), 109-111.

Font, V., Godino, J. D., \& Amore, B. D. (2015). Onto-Semiotic Representations in Mathematics Education. 27(2), 2-7.

Font, V., Godino, J. D., \& Gallardo, J. (2012). The emergence of objects from mathematical practices. Educational Studies in Mathematics, 82(1), 97-124. doi: 10.1007/s10649-0129411-0

Godino, J. D., Batanero, C., \& Font, V. (2007). The onto-semiotic approach to research in mathematics education. Zdm, 39(1-2), 127-135. doi: 10.1007/s11858-006-0004-1

Godino, J. D., Batanero, C., \& Roa, R. (2005). An onto-semiotic analysis of combinatorial problems and the solving processes by university students. Educational Studies in Mathematics, 60(1), 3-36. doi: 10.1007/s10649-005-5893-3 
Godino, J. D., Font, V., Wilhelmi, M. R., \& Lurduy, O. (2011a). Why is the learning of elementary arithmetic concepts difficult? Educational Studies in Mathematics, 77(2), 247-265. doi: 10.1007/s10649-010-9278-x.

Godino, J. D., Font, V., Wilhelmi, M. R., \& Lurduy, O. (2011b). Why is the learning of elementary arithmetic concepts difficult? Semiotic tools for understanding the nature of mathematical objects. Educational Studies in Mathematics, 77(2-3), 247-265. doi: $10.1007 / \mathrm{s} 10649-010-9278-x$

Godino, J. D., \& Pino-Fan, L. (2013). The mathematical knowledge for teaching. A view from onto-semiotic approach to mathematical knowledge and instruction. In Proceedings of the Eighth Congress of the European Society for Research in Mathematics Education (pp. 3325-3326). Antalya, Turkey: CERME.

Montiel, M., Wilhelmi, M. R., Vidakovic, D., \& Elstak, I. (2009). Using the onto-semiotic approach to identify and analyze mathematical meaning when transiting between different coordinate systems in a multivariate context. Educational Studies in Mathematics, 72(2), 139-160. doi: 10.1007/s10649-009-9184-2

Neto, T., Breda, A., Costa, N., \& Godino, J. D. (2007). Resorting To Non Euclidean Plane Geometries To Develop Deductive Reasoning an Onto-Semiotic Approch.

Peraturan Menteri Negara Pendayagunaan Aparatur Negara dan Reformasi Birokrasi Nomor 16 Tahun 2009 Tentang Jabatan Fungsional Guru dan Angka Kredit.

Permendikbud Nomor 22 Tahun 2016 Tentang Standar Proses. 